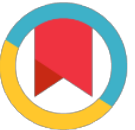

Check for updates

*For correspondence:

pvphuc@hcmuns.edu.vn

Competing interests: The authors declare that no competing interests exist.

Received: 2017-08-15

Accepted: 2017-08-29

Published: 2017-09-05

Copyright The Author(s) 2017. This article is published with open access by BioMedPress (BMP).

This article is distributed under the terms of the Creative Commons Attribution License (CC-BY 4.0) which permits any use, distribution, and reproduction in any medium, provided the original author(s) and the source are credited.

\title{
Welcome to CRRM2017
}

WELCOME LETTER

\author{
Thuoc Linh Tran ${ }^{1}$, Fuyu Tamanoi ${ }^{2}$, Mong-Hong Lee ${ }^{3}$, Phuc Van Pham ${ }^{1, *}$ \\ 'University of Science, VNUHCM, Ho Chi Minh city, Vietnam \\ 2University of California, Los Angles, USA \\ ${ }^{3}$ MD Anderson Cancer Center, University of Texas, Houston, USA
}

On behalf of the entire the international conference Innovations in Cancer Research and Regenerative Medicine 2017 (CRRM2017) Organizing Committee, we would like to extend to you a warm welcome to Ho Chi Minh city, Vietnam to join the 3rd international conference of CRRM.

In this time, CRRM has got some changes with more plenary sessions, more sessions, more oral invited speakers and especially a day of pre-conference. With two main topics of cancer research and regenerative medicine, this conference is organized some parallel sessions with different topics of cancer research and regenerative medicine that audiences can arrange your sufficient time for networking and speaking to our commercial partners

From the basic science to clinical trials, all sessions at the conference will cover from gene to human body. Therefore, we believe that every session will provide the exciting presentations for attendees at all levels from students to scientists as well as researchers. With this conference, all authors do not only share their latest results, but also can publish their works in the reputed journals. That is a reason of the keywords for this conference as Share \& Publish.

Like many developing countries, Vietnam has no shortage of health challenges, from infectious diseases such as annual flu epidemics to rising rates of unmet and chronic illnesses such as cancers and diabetes. Vietnam also has to contend with increasing resistance to drugs for killer diseases including AIDS, tuberculosis, and malaria. There is, however, increasing evidence that Vietnamese researchers are rising to the challenge of harnessing biotechnology to improve health care for healthier society as well as advancing the sciences. The biomedicine progresses in Cancer Research, and Regenerative Medicine in Vietnam include gene diagnostics for genetic disorders of human diseases, infectious pathogens; in-vitro production of therapeutic proteins including insulin, IFNs or bio-similar forms of monoclonal antibodies for targeted therapies; biomaterials; cell therapy; stem cell therapy and tissue engineering.

In this conference, with 14 sessions of 100 oral presentations and 100 poster presentations, all latest topics of cancer research and regenerative medicine will be focused. New markers of cancers, immunotherapy for cancers and stem cells as well as tissue engineering are hot topics of CRRM2017. In addition to the conference program, there is an extensive set of pre-conference and lunch-on innovation showcases for on 10th and 11 th Sept, respectively.

As ever, we are exceedingly grateful for the support of sponsors for the CRRM2017. More than ever have taken space in the exhibition area, and we encourage attendees to avail themselves of the opportunities to visit the exhibit booths and corporate symposia.

We wish to thank everyone who helped so enthusiastically in the organization of the conference. Our thanks also go out to all of the speakers who have generously agreed to share their studies, experiences at this conference.

We are sure that you will have a highly informative and, we hope, entertaining time with us here in Ho Chi Minh city. 